\title{
ON THE AUSTRALIAN BEMBIDIIDES REFERABLE TO THE GENUS TACHYS, WITH THE DESCRIP- TION OF A NEW ALLIED GENUS PYRROTACHYS.
}

\section{By Thomas G. Sloane.}

In the present paper I have placed in the genus Tachys all the Australian Bembidiides which have the anterior tibiæ decidedly oblique above the apex on the external side; normally also a striole is present on the apical declivity of each elytron, but this character is not invariable.

The most important contribution to the knowledge of the Bembidiides of Australia is Sir William Macleay's notice and descriptions of seventeen species from Gayndah, all of which he referred to the genus Bembidium.* I have seen the types of Macleay's species in the Australian Museum, Sydney. Three of them, viz., B. amplipenne, B. bipartitum and B. sexstriatum, I am unable to deal with, as I do not possess specimens; and, not residing in Sydney, I cannot see the types at present. Specimens of the eleven species to which the remaining fourteen must be reduced are in my possession. Nine are dealt with in the present paper; the tenth is Bembidium jacksoniense, Güer., = B. subviride, Macl., the eleventh, Bembidium gagatinum, Macl., is not a Bembidiid at all, but a Harpalid which may be referred, at least tentatively, to the genus Thenarotes. $\dagger$

* Vide Trans. Ent. Soc. N.S. W. 1873, ii. pp. 115-120.

+ Bembidium flaripes, Macl., is a synonym of B. gagatinum, Macl., being founded on an immature specimen; the species, which extends as far south as the Murray River, may be known in future as Thenarotes gagatinus, Macl. 
The principal features used in the synoptic table of species which follows seem to divide the species here placed in Tachys into distinctive groups that are readily separated from one another; indeed the most important of these groups are apparently so distinct that they might be removed from Tachys altogether and formed into separate genera; but to do this would require a fuller knowledge than I possess of the genera now regarded as capable of maintenance among the Subulipalpi, and of the system adopted in classifying them. The minor features used in the table for separating closely allied species from one another are not perhaps always the best that could have been chosen, though they have seemed to me to be so.

The following species of Tachys, described by the Rev. Thos. Blackburn, are unknown to me in nature, and, for that reason, have not been included in the table, viz., $T$. baldiensis, $T$. infuscatus, and T'. adelaidre.

\section{Genus Tachys.}

Owing to the variable number of striæ on the elytra among the species of the genus Tachys (the full number is eight striæ and a marginal channel, but this only occurs in $T$. yarrensis, Blkb., among the species known to me) the ordinal number to indicate the stria next the marginal channel would vary, and as this stria seems a feature of great classificatory importance it becomes needful to use an unvarying term for it. I therefore call it the submarginal stria. The interstice between the submarginal stria and the marginal channel I call the lateral interstice.

\section{Table of Species known to me.}

I. Elytra with submarginal stria well marked.

A. Prothorax with a submarginal lateral carina near base.

b. Upper surface shagreened and finely punctulate (unicolorous)................. T. brunnipennis, Macl.

bb. Upper surface shagreened, impunctate (bicolorous) .......................... T. ectromioides, Sl.

AA. Prothorax without a submarginal lateral carina near base. 
C Marginal channel of elytra simple, ateral interstice convex.

Prothorax without a dẹtiform proection on sides before base.

. Elytra sexstriate on each side of suture.

$f$. Elytra quadrimaculate, fifth stria reaching border of base .......... T. buprestioides, Sl.

ff. Elytra bimaculate, fifth stria not reaching base.

$e e$. Elytra quinquestriate on each side of suture

g. Elytra quadrimaculate. T. striolatus, Macl.

gg. Elytra bimaculate T. bipustulatus, Macl.

* eee. Elytra bistriate on each side of suture. T. curticollis, Sl.

eeee. Elytra unistriate on each side of suture T. iaspideus, Sl.

$d d$. Prothorax with a dentiform projection on sides a little before base.

$h$. Elytra bistriate on each side of suture ........................... T. spenceri, Sl.

$h h$. Elytra unistriate on each side of suture. T. bistriatus, Macl.

CC. Marginal channel of elytra punctate, lateral interstice depressed.

$i$. Elytra with eight punctate striæ on each (seventh as well marked as others' T. yarrensis, Blkb.

ii. Elytra with seventh stria obsolete.

$j$. Lateral basal foveæ of prothorax concare, bordered by the widely upturned lateral border.

$k$. Elytra sexstriate on each side of suture, lateral margin of prothorax with one setigerous puncture anteriorly

T. monochrous, Schaum.

* T. ovensensis, Blkb., (a specimen of which I received from Mr. Blackburn while this paper was in the press) belongs to section "eee." For some differences between it and $T$ curticollis, see description of the latter (post, p. 364). 
$k k$. Elytra quinquestriate on each side of suture, margin of prothorax plurisetose near anterior angles

$j j$. Lateral basal foveæ of prothorax concave, divided from lateral border by a raised space ........

$j j j$. Posterior angles of prothorax forming the apex of a triangular marginal process.

l. Colour piceous red, elytra with testaceous ante-apical maculæ T. semistriatus, Blkb.

ll. Colour black ..................... T. habitans, sl.

II. Elytra with submarginal stria obsolete on sides.

M. Form short, very convex; prothorax not perceptibly narrowed to base; elytra lævigate, unistriate on each side of suture..... T. ovatus, Macl.

MM. Form varying, prothorax evidently narrowed to base.

N. Head impunctate, frontal impressions deep, oblique (converging anteriorly); third interstice of elytra biptinctate on dise.

$o$. Elytra with six rows of strong punctures on each side of suture........ T. mitchelli, Sl.

oo. Elytra with three or four punctulate striæ on each side of suture.

NN. Head punctate, frontal impressions long, deep, narrow, parallel.

$p$. Surface of prothorax impunctate T. leai, Sl.

$p p$. Surface of prothorax minutely and rather densely punctulate T. murrumbidgensis, Sl.

NNN. Head impunctate, frontal impressions wide, shallow.

$q$. Each elytron bipunctate on disc, recurved striole of apex obsolete $T$. captus, Blkb.

$q q$. Each elytron unipunctate on disc

$r$. Elytra more or less distinctly striate on disc, recurved striole of apex well marked. 
* $s$. Discoidal puncture of elytra placed a little before middle nearer suture than margin.

$t$. Elytra depressed, sides parallel; prothorax piceous black

T. uniformis, Blkb.

tt Elytra lightly convex, sides rounded; prothorax testaceous.

$u$. Elytra with strongly impressed punctulate striæ on disc, base testaceous (a wide black fascia across middle of elytra)...........T. atriceps, Kacl.

uи. Elytra with faintly impressed striæ on disc, middle of base piceous... T. lindi, Blkb.

ss. Discoidal puncture of elytra placed about anterior third, nearer margin than suture... T. transversicollis, Macl.

$r r$ Elytra lævigate, nonstriate, recurved striole of apex obsolete ..................... T. macleayi, Sl.

Tachys BRUnnipennis, Macleay.

T. (Bembidium) brunnipennis, Macl., presents the characteristic features of Tachys, viz., the anterior tibiæ oblique above apex on external side, and the elytra with the sutural stria recurved at apex; the recurved apical striole is very near the margin, and is divided from the submarginal stria by a narrow subcarinate interstice.

Hab. : Queensland-Cairns (Froggatt), Port Denison and Gayndah (Masters).

\section{TACHYS ECTROMioIDEs, n.sp.}

Oval, subdepressed. - Prothorax transverse, much wider at base than apex, posterior angles rectangular: elytra oval, lightly

* T. similis, Blkb., (a specimen of which was received from Mr. Blackburn too late to be worked into the table) comes into section " $s . "$ It resembles $T$, uniformis, Blkb., in facies, but differs in colour. 
convex, finely striate; third stria more strongly impressed on apical declivity and joining sutural stria at apex; submarginal stria faintly impressed, very near margin. Head dark piceous, labrum testaceous; prothorax piceous brown, lateral margin and middle of base testaceous; elytra testaceous, a very wide dark piceous fascia across dise considerably behind base, apex widely piceous; legs testaceous, antennæ infuscate, basal joints testaceous.

Head depressed, hardly impressed laterally; a feeble oblique ridge on each side near eyes; clypeal suture finely impressed; clypeus bifoveolate; eyes large, convex. Antennæ filiform, not long. Prothorax transverse $(0.65 \times 0.85 \mathrm{~mm}$. $)$, widest about anterior third, roundly declivous to lateral margin anteriorly; sides strongly rounded to apex, straight posteriorly and hardly narrowed to base; anterior margin truncate; anterior angles not marked; basal angles rectangular, acute; base lightly and roundly produced backwards in middle; lateral border reflexed, reaching to sides of head at apex; lateral channel wide, narrowed to anterior angles; median line deep, a strongly marked arcuate transverse line defining basal part of prothorax; a lightly carinate longitudinal submarginal ridge near each basal angle. Elytra oval, convex, much wider than prothorax $(2 \times 1.3 \mathrm{~mm}$. $)$; sides rounded; shoulders rounded; five inner striæ lightly impressed, finely crenulate, sixth and seventh obsolete; interstices depressed, first narrow on apical declivity, second and third ampliate on apical declivity, third with two small setigerous punctures-the anterior just before, the posterior just behind discoidal piceous fascia; lateral interstice very narrow, not convex, having four setigerous punctures behind shoulders and about same number towards apex; base not bordered; lateral border narrow, reflexed, forming a very slight prominence at humeral angles. Anterior tibiæ incrassate, oblique above apex on external side; a short acute spur above obliquity.

Length 3 , breadth $1.3 \mathrm{~mm}$.

Hab.: West Australia-Donnybrook (Lea; Coll. Lea, unique).

I am not sure that $I$ am right in putting this species in the genus Tachys; no allied species is known to me; though $\mathrm{I}$ have 
placed it with T. brunnipennis, Macl., in the table of species at p. 356 ; this has only been done on account of the submarginal carina near basal angle of prothorax, and not because I have thought there is any close affinity between these species. In general appearance it has a resemblance to a Lebiid of the genus Surothrocrepis or Ectroma. If the ground colour of the elytra be considered piceous, then the base (widely), the margin and a narrow fascia just above the apical declivity would be described as testaceous; the dark-coloured parts of the elytra do not anywhere reach nearer the sides than the submarginal stria.

\section{Tachys BUPRestioides, n.sp.}

Robust, oval, convex. Head wide; prothorax transverse, wider across base than apex: elytra ovate, six inner striæ strongly impressed on each elytron; lateral stria and marginal channel strongly impressed, interstice between them convex. Bronzed black, each elytron with an elongate macula behind shoulder and a reniform macula on apical third testaceous, legs (excepting coxæ) testaceous, antennæ infuscate, under surface piceous, apical segments of abdomen reddish.

Head convex, finely shagreened, lightly bi-impressed; clypeal suture finely and distinctly marked; eyes large, convex, not globose. Maxillary palpi with penultimate joint elongate, thick, incrassate, setose; apical joint very small. Prothorax transverse, widest at anterior marginal puncture; sides strongly rounded on anterior two-thirds, lightly narrowed posteriorly, straight before base; anterior margin emarginate; anterior angles obtuse but marked; basal angles rectangular; base truncate on each side, roundly produced backwards in middle; border narrow, reflexed; median line very lightly impressed; a straight transverse line near base, this line strongly impressed in middle; lateral basal impressions short, placed at each side of rounded middle part of base. Elytra wider than prothorax, convex; sides rounded; shoulders rounded; striæ simple, only first reaching apex, first, second and fifth reaching base, second, third and fourth extending past posterior margin (between macula and suture) of ante-apical 
macula, fifth and sixth not extending past anterior margin of ante-apical macula, fifth reaching basal border, sixth not reaching base, seventh obsolete (only noticeable under a lens on black part of space between sixth and eighth); lateral stria deeply impressed, curving towards margin posteriorly; inner interstices convex; submarginal interstice very convex, bipunctate near base and at beginning of apical curve; lateral border extending on to base as far as fifth stria. Anterior tibiæ shortly oblique above apex on external side; a short acute spur above obliquity.

Length $3 \cdot 1$, breadth $1 \cdot 3 \mathrm{~mm}$.

Mab. : King's Sound (Froggatt; Macleay Museum).

Allied to T. striolatus, Macl., but larger and broader; the prothorax is more transverse and wider across the base, less rounded on the sides, the anterior angles more strongly marked; the posthumeral macula of the elytra is elongate; there are six (not five) striæ on each elytron, the first, second and fifth striæ reaching the base. The whole of the dark part of the elytra, excepting the sides, is strongly striate; the third and fourth striæ do not reach quite to the base, but there is not the wide lrvigate basal space that is so noticeable in T. striolatus.

\section{TACHYS FrogGatti, n.sp.}

Robust, oval, convex. Head wide, lightly bi-impressed; prothorax transverse, wider across base than apex; elytra ovate, six inner striæ strongly impressed, lateral stria and marginal channel strongly impressed, interstice between them convex. Black, head and prothorax with a greenish tinge; each elytron with a testaceous macula about posterior third; under surface piceous, legs (excepting coxæ) testaceous, antennæ infuscate towards apex.

Head, prothorax and legs in every way resembling those of $T$. buprestioides, Sl. Elytra similar to those of T'. buprestioides in shape, sides and apex; striæ hardly so deep, first entire, second and third reaching almost to base, 4-6 rising at a considerable distance from base on one level.

Length $2 \cdot 2-2 \cdot 6$, breadth $1-1 \cdot 15 \mathrm{~mm}$.

Ilab. : King's Sound (Froggatt; Macleay Museum). 
Differs from TT. buprestioides by its smaller size, by the absence of the post-humeral maculæ of the elytra, and by the fifth stria not reaching the base. It is closely allied to $T$. bipustulatus, Macl., from which it differs by having six (not five) striæ on each elytron and the striæ reaching nearer the base--especially the three inner ones.

Tachys striolatus, Macleay.

T. (Bembidium) striolatus, Macl., has been redescribed and placed in Tachys by the Rev. Thos. Blackburn.*

Habits :-Riparian, running beside the margins of streams, or on sandy margins of pools, during summer months.

Hab.: Queensland-Gayndah (Masters); N.S. Wales-Narrandera and Mulwala (Sloane); Victoria-near Bright (Blackburn).

\section{Tachys bipustulatus, Macleay.}

T. (Bembidium) bipustulatus, Macl., agrees in all points of structural detail and in striation of elytra with T. striolatus, Macl.

Habits:-Riparian; two specimens occurred to me on the muddy edge of pools in Houlaghan's Creek near Junee.

Hab. : Queensland-Gayndah (Masters); N.S. Wales-Forest Reefs (Lea), Junee District (Sloane).

\section{Tachys curticollis, n.sp.}

Oval, convex. Prothorax transverse, evidently a little wider across base than apex, posterior angles rectangular and acute; elytra lævigate on disc, bistriate on each side of suture, lightly bipunctate near second stria. Black, or piceous black; each elytron with a dull reddish spot near shoulder and another at beginning of apical declivity; legs pale testaceous.

* Vide P.L.S.N.S.W. 1891 v. (2), p. 785, and Trans. Roy. Soc. S. Aust. 1894, xviii. p. 139. 
Head smooth; frontal impressions long, straight, diverging backwards, extending forward to labrum; eyes prominent, hemispherical. Prothorax lævigate, convex, short, transverse, widest just behind anterior marginal puncture; basal part defined by a transverse impression; sides lightly rounded anteriorly, gently narrowed to base, meeting base at right angles; base sloping lightly forward on each side to posterior angles; lateral border reflexed, becoming wider towards base; median line obsolete; a flattened depressed space near each basal angle; a light transverse linear impression (hardly punctulate) connecting the lateral basal depressions. Elytra much wider than prothorax, oval, truncate at base (shoulders rounded), convex, declivous to base; striæ simple, first entire, second as strongly impressed as first, not reaching base or apical declivity, a deep lateral stria besides marginal channel on each elytron. Anterior tibiæ oblique above apex on external side, a spiniform spur above obliquity.

Length 2, breadth $1 \mathrm{~mm}$.

Hab. : N.S. Wales-Tweed River (Jea; March, 1892), Cootamundra District (Sloane).

At a casual glance this species might be taken for a small form of $T$. bistriatus, Macl., but it differs decidedly from that species by having a second stria outside the sutural one extending from the anterior discoidal puncture to the apical declivity and by the shape of the prothorax, which is much wider at the base and has the basal angles rectangular, the sides not having a prominent angular projection above the base as in T. bistriatus. It is somewhat like $T$. ovensensis, * Blkb., from which it differs by having a post-humeral reddish spot on each elytron; by the form of the frontal impressions which are further from the eyes; narrow, and extend obliquely forward till they reach the anterior margin of the clypeus; by the sides of the prothorax being less rounded on the sides and wider at the base.

* In $T$. ovensensis, Blkb., the head and prothorax are similar in shape, \&c., to those of T. striolatus, Macl. 


\section{Tachys iaspideus, n.sp.}

Elongate-oval; prothorax transverse (not short); elytra lævigate, each elytron unistriate near suture and with recurved stria of apex distinct. Shining, polished, reddish or reddish brown; elytra lighter coloured than prothorax near base, almost black across middle and near apex, a large yellowish-red spot behind posterior discoidal puncture on each elytron.

Head smooth, convex, lightly bi-impressed between eyes; the impressions short, not extending to clypeus; eyes large, convex. Prothorax small, transverse, a little wider than head, widest a little before middle, lightly narrowed to base, convex, lævigate, not declivous to middle of base, not transversely impressed across base; sides lightly rounded, gently narrowed (not sinuate) to posterior angles; apex and base truncate; posterior angles obtuse, not prominent; border narrowly reflexed; median line wanting; a lightly marked wide oblique impression at each basal angle. Elytra much wider than prothorax, suboval, convex, a little depressed on disc; base subtruncate; humeral angles rounded; apex narrowly rounded; one simple stria on each side of suture; one deep lateral stria besides the marginal channel on each elytron; lateral interstice convex and depressed posteriorly; lateral margin interrupted just behind shoulders causing the margin of the humeral angles to project slightly; two punctures placed longitudinally on dise of each elytron.

Length $2 \cdot 8$, breadth $1 \cdot 3 \mathrm{~mm}$.

\section{Hab. : N.S. W.-Inverell, Tamworth (Lea).}

This species exactly resembles $T$. spenceri, Sl., in shape and appearance; the marked features distinguishing it from that species are $(a)$ the absence of any projection at the basal angles of the prothorax, and $(b)$ the elytra having only one stria on each side of the suture, not two as in $T$. spenceri. The penultimate joint of the maxillary palpi is large and pyriform, the apical joint a mere short spike. The general colour is like that of polished yellowish-brown jasper. 


\section{TACHYS SPENCERI, Sloane.}

Habits:-Found under stones besides edge of water (Spencer). Hab.: Central Australia -Larapintine Region (Spencer); West Australia_King's Sound (Froggatt).

\section{Tachys bistriatus, Macleay.}

T. (Bembidium) bistriatus, Macl. (= Bembidium convexum, Macl.), has a short recurved striole on the middle of the apex of each elytron; the posterior angles of the prothorax form a small triangular prominence on the sides a little before the base itself. I have carefully compared the types of Bembidium bistriatum, Macl., and B. convexum, Macl., with one another and find them one species.

Hab.: Queensland-Gayndah (Masters); N.S. Wales-Tweed and Clarence Rivers (Lea).

TaChys yarrensis, Blackburn.

Habits :-Found under logs and débris in very damp situations.

Hab. : Victoria--Upper Yarra (French); N. S. Wales-- Mulwala and Urana (Sloane), Tamworth (Lea).

\section{Tachys monochrous, Schaum.}

No doubt remains in my mind, after comparing specimens of Bembilium punctipenne, Macl., with the description of Tachys monochrous, Schaum, but that the species are synonymous.

Habits :-Found under logs in very damp situations.

Hab.: Victoria-Lilydale (Sloane); N. S. Wales-Windsor and Tamworth (Lea), Ourimbah (Fletcher); Queensland-Gayndah (Masters).

\section{TACHYS SETICOLLis, n.sp.}

Oval, robust. Prothorax lightly transverse, strongly narrowed to base, basal angles rectangular, margin plurisetose near anterior angles: elytra widely ovate; five rows of punctures and a submarginal stria on each elytron; recurved striole of apex distinct, rather short; two fine setigerous discoidal punctures on third 
interstice. Clear ferruginous red, subtestaceous above apical declivity of elytra; legs testaceous; antennæ ferruginous, basal joint testaceous.

Head convex; front widely but rather deeply bi-impressed; eyes large, convex. Antennæ short, stout, filiform (reaching back a little behind base of prothorax). Prothorax broader than long, widest a little before anterior third, evidently narrower across base than apex; disc lightly convex, rather depressed in middle, lightly declivous to basal area; sides strongly rounded anteriorly, shortly, strongly and roundly narrowed to anterior angles, strongly sinuate posteriorly, meeting base at right angles; -anterior margin truncate; anterior angles not marked; base widely truncate in middle, oblique on each side; basal angles prominent, acute; basal area depressed, well marked, extending to lateral border at each side, defined anteriorly by a strongly marked transverse punctate impression; lateral border very narrow on rounded part of sides, thick and strongly reflexed near basal angles; median line very lightly impressed on disc; four or five setigerous marginal punctures between anterior third and anterior angles. Elytra widely ovate; base roundly truncate; humeral angles not marked; sides rounded; first stria entire, punctate for more than half its length, simple posteriorly; striæ 2-5 consisting of rows of closely set strong punctures extending from base to lighter-coloured lævigate apical part of elytra; submarginal stria punctate; lateral interstice not convex; marginal channel closely punctate; the punctures from shoulder to apical curve each bearing a long seta.

Length $2 \cdot 25$, breadth $1 \mathrm{~mm}$.

Hab.: North West Australia-King's Sound (Froggatt; Macleay Museum).

Allied to T. monockrous, Schaum, but differing by its shorter, wider, and rather less convex form; the prothorax wider, more strongly narrowed to base, disc flatter and less strongly declivous to base, margin plurisetose behind anterior angles; elytra shorter, wider, less convex, five- (not six-) striate. 
TACHYS FLINDERSI, Blackburn.

T. flindersi, Blkb. = Tachys $($ Bembidium $)$ rubicundus, Macl., I have no doubt about the correctness of this synonymy; Macleay's name was used in the genus Tachys as long ago as 1850, therefore the later name must be adopted.*

Habits :-Found under logs and stones in very damp situations.

Hab.: Queensland-Gayndah (Masters); N.S. Wales-Tamworth (Lea', Sydney and Wagga Wagga (Sloane); VictoriaUpper Ovens River (Blackburn), Lilydale (Sloane); Central Australia (Spencer); West Australia-Darling Ranges (Lea).

\section{Tachys habitans, n.sp.}

Oval, convex. Prothorax convex, subcordate: elytra oval, convex, six rows of punctures on basal part; apex lævigate; submarginal stria indicated, punctate; lateral interstice very narrow, not convex; recurved striole of apex well marked. Black, shining; legs piceous, mandibles piceous brown.

Head convex, smooth; front widely bi-impressed anteriorly. Prothorax small, lævigate, widest rather before middle, not narrower across posterior angles than across apex; sides strongly rounded on anterior two-thirds, shortly sinuate before posterior angles; anterior margin truncate; anterior angles not marked; posterior angles prominent, acute; base lightly oblique on each side behind posterior angles; lateral border narrow, reaching sides of head; median line obsolete; a lightly marked impunctate impression across base near margin; lateral basal foveæ round, deep, placed near margin at basal angles. Elytra much wider than prothorax; six rows of punctures and a submarginal stria on each elytron; first stria entire, finely and closely punctate on disc, simple posteriorly, others (consisting of rows of punctures) not reaching base, fifth and sixth short (sixth sometimes consisting of only two punctures); third interstice with two fine setigerous

* Vide P.L.S.N.S.W. 1894, ix. (2) p. 90, for a note by the Rev. Thos. Blackburn on this subject. 
punctures, the anterior hardly noticeable among basal puncturation, the posterior on lævigate portion of elytra a little before apical declivity; external margin of apical striole carinate; marginal channel finely punctate; border passing round humeral angle on to base as far as fourth stria.

Length 2, breadth $0.8 \mathrm{~mm}$.

Hab.: West Australia_Darling Ranges, Bridgetown, Pinjarrah (Lea).

Allied to T. semistriatus, Blkb., but differing in colour; its more elongate shape; the prothorax with posterior angles more prominent and explanate; the elytra proportionately narrower, less strongly punctate, with fewer punctures in the rows, especially the fifth and sixth.

Tachys ovatus, Macl.

T. (Bembidium) ovatus, Macl., = Bembidium bifoveatum, Macl.; I have seen the types and find these two species synonymous. It has a distinct recurved striole at apex of each elytron. Though usually of a pale testaceous colour, a specimen that is subpiceous has been sent to me by Mr. A. M. Lea, as coming from the Tweed River.

Habits :- Under stones in very damp situations.

Hab. : Queensland-Gayndah (Masters); N.S. Wales-Tweed River, Clarence River, Inverell, Tamworth and Sydney (Lea).

\section{Tachys australicus, n.sp.}

Robust, very convex. Prothorax convex, transverse, rounded on sides, a little wider across base than apex; elytra very convex, lightly striate near suture, sides smooth. Head and prothorax red or testaceous red, eyes black, elytra piceous or piceous black.

Head smooth, convex; front with two rather wide nearly parallel impressions; space between these impressions convex. Prothorax smooth, transverse, convex; sides strongly rounded without any sinuosity before posterior angles, oblique to base on each side behind posterior angles; basal area short, convex, defined by a strong transverse impression; posterior angles not 
prominent, their summit acute; lateral basal foveæ obsolete. Elytra wider than prothorax, oval, very convex, declivous to peduncle, truncate on base; shoulders rounded, not marked; two, or at most three, lightly impressed striæ near the suture, first entire, lightly punctulate on disc, others only marked on disc (not reaching base), lightly punctulate; space between striæ and margin smooth and without discoidal punctures; recurved striæ of apex obsolete; marginal channel not deep along sides; three strong punctures near margin behind each shoulder, and two strong submarginal foveiform impressions on apical third.

Length $1 \cdot 7$, breadth $0.75 \mathrm{~mm}$.

Hab. : N.S. Wales-Tweed River, Windsor (Lea).

The affinity of this little species is to $T$. mitchelli, Sl., from which it differs by its smaller size; dark coloured elytra; shorter and less oblique frontal impressions; elytra with only two or three striæ next the suture marked, the remaining part smooth (the striæ are linear and hardly punctulate, not rows of punctures as in T. mitchelli), \&c.

\section{TACHys LeaI, n.sp.}

Elongate-oval ; prothorax convex, transverse, subcordate, narrower between posterior angles than at apex; elytra depressed, truncate at base, finely punctate-striate. Black, shining; legs and under surface piceous brown; antennæ piceous brown at base, infuscate towards apex.

Head convex, smooth; front and vertex minutely punctulate; front bi-impressed; the impressions long, straight, deep, hardly diverging backward, extending forward to base of labrum; space between frontal impressions convex; clypeal suture obsolete; clypeus declivous to labrum; eyes convex, not very prominent. Prothorax a little wider than head, transverse, widest a little before the middle, lightly narrowed to base, convex, lævigate; anterior margin truncate; base truncate across peduncle, a little oblique on each side behind posterior angles; sides unequally rounded on anterior three-fourths, shortly sinuate before posterior angles; these acute, prominent, placed a little before the actual 
base; a well marked transverse impression extending across base just behind posterior angles and defining the basal part; median line very lightly impressed. Elytra wider than prothorax $(1.5 \times 1 \mathrm{~mm}$.), depressed on disc; sides lightly rounded; base truncate, hardly emarginate; shoulders rather prominent, rounded; five finely punctulate lightly impressed striæ on each elytron (exclusive of marginal channel), first entire, flexuous (approaching suture) near base, second almost equally impressed as first on dise, obsolete towards base and apex, third and fourth much more lightly impressed, not extending towards base beyond anterior discoidal puncture, fifth strongly impressed on anterior fourth near each shoulder, obsolete for remainder of its course; scutellar striole wanting; interstices flat, fourth with two discoidal punctures, the anterior at about one-fourth the length of elytra from base, the other a little behind middle on course of third stria; third interstice very finely punctulate on apical declivity; marginal channel deeply impressed along sides, three or four rather strong punctures behind the shoulders; apical declivity with two oblique impressions on each side, the external strongly impressed near the margin (extending round the apex to join the sutural stria), the inner short, placed closed to the external one.

Length $2 \cdot 4$, breadth $1 \mathrm{~mm}$.

Hab. : N.S. Wales-Tamworth (Lea).

Sent to me by Mr. A. M. Lea, to whose generosity I am indebted for a specimen, and to whom I dedicate it.

In all details of structure this species resembles $T$. murrumbidgensis, Sl., from which it differs by its larger size, wider and more convex shape, impunctate prothorax, black colour, dc. These two species form a well marked group among the Australian Bembidiides, and it is evident they can only provisionally be considered congeneric with such species as Tachys monochrous, Schaum, T'. findersi, Blkb., \&c.

Tachys murrumbidgensis, Sloane.

Hab. : N.S. Wales-Narrandera (Sloane), Tamworth (Lea!. 
TaChys Captus, Blackburn.

Habits :-Found under sticks and stones in damp situations.

Hab.: South Australia_Port Lincoln, Adelaide (Blackburn) ; N.S. Wales-Mulwala, Urana, Narrandera and Junee (Sloane), Windsor and Tamworth (Lea).

Tachys uniformis, Blkb.

Hab. : South Australia-Adelaide and Port Lincoln (Blackburn); West Australia_Beverley (Lea).

\section{Tachys atriceps, Macleay.}

Habits :- Found under logs in damp places near water.

Hab. : Queensland-Gayndah (Masters); N.S. Wales-Carrathool, Narrandera and Mulwala (Sloane); King's Sound (Froggatt).

\section{TAChys Lindi, Blackburn.}

Among the Bembidiides from King's Sound, in the Macleay Museum, the commonest species is one that I take to be $T$. lindi, Blkb. (var.) It differs from a type specimen of $T$. lindi received from Mr. Blackburn by being smaller (length $2.5 \mathrm{~mm}$.) and of a lighter build. T. lindi seems to be a variable species in size and colour marks; its constant characters appear to be (a) a more or less testaceous macula behind the shoulder and another towards the apex of each elytron, $(b)$ the anterior discoidal puncture of the elytra placed about the middle of their length on the course of the third stria. Many of the specimens from King's Sound (evidently immature) have the elytra almost wholly testaceous with variously placed cloudy dark marks.

Hab.: South Australia-Port Lincoln District (Blackburn); N.S. Wales_Windsor (Lea); West Australia_-Swan River and Beverley (Lea); Variety? King's Sound (Froggatt).

\section{Tachys transversicollis, Macleay.}

The colour varies from pale testaceous (immature specimens) to testaceous with the disc of the elytra infuscate, or even the whole 
of the elytra infuscate; the head is blackish in mature specimens; the elytra are usually iridescent; the discoidal puncture on each elytron is situated along the fifth stria, considerably before the middle, - this is a constant character and valuable as an aid in the recognition of this species; the striæ of the elytra are faint and become obsolescent after the third.

Habits:-Found under sticks or stones near water in very damp situations.

Hab.: Queensland-Gayndah (Masters), Brisbane (Coates); N. S. Wales-Clarence River (Lea), Junee, Carrathool, Urana, and Mulwala (Sloane).

\section{TaChys MaCleayi, n.sp.}

Oval, subdepressed, lævigate. Head large, wide between eyes, prothorax subcordate; posterior angles strongly marked, acute; base (behind posterior angles) narrower than apex: elytra smooth, widely and lightly convex; two discoidal punctures on each elytron. Head piceous, prothorax obscure testaceous; elytra black with a large quadrate spot at shoulder, and a smaller round spot above apical declivity on each elytron pale testaceous; legs pale testaceous; antennæ pale testaceous with joints 3-6 infuscate.

Head lightly and widely bi-impressed between eyes. Antennæ filiform, long, slender. Prothorax lightly transverse, widest at anterior marginal puncture, angustate posteriorly; sides strongly rounded anteriorly, decidedly sinuate before posterior angles; anterior angles rounded; posterior angles triangular, prominent, acute; basal angles rounded; lateral border narrowly reflexed, reaching to sides of head; median line distinct; a well marked impunctate transverse line defining basal part of prothorax and reaching sides behind posterior angles. Elytra much broader than prothorax, wide between shoulders; base lightly rounded and margined on each side of peduncle; humeral angles obtuse; sides rounded, narrowed rather obliquely to apex; each elytron obtusely rounded at apex; three faint substriate impressions at apex of each elytron; anterior discoidal puncture just behind humeral 
macula, posterior puncture in middle of subapical macula; border finely reflexed, extending from peduncle to apex; three or four setigerous punctures near margin behind shoulders, three foveiform submarginal impressions towards apex of each elytron.

Length 3 , breadth $1.25 \mathrm{~mm}$.

Hab. : King's Sound (Froggatt; Macleay Museum).

I know no Bembidiid closely allied to T. macleayi; its affinity is probably with Bembidium bipartitum, Macl., a species I have never critically examined. The legs and antennæ are long, the antennæ reaching back as far as the posterior maculæ of the elytra; the elytra are smooth without a submarginal stria on sides, and the marginal channel is not impressed.

Pyrrotachys, n.gen.

Form parallel, depressed.

Head setigero-punctate, strongly constricted behind eyes; frontal impressions arcuate, extending backwards behind eyes.

Mandibles long, prominent, decussating.

Palpi with penultimate joint lævigate, swollen; terminal joint elongate, cylindrical.

Antennce long, light, compressed, not narrowed to apex; terminal joint long, oval.

Prothorax setigero-punctate.

Elytra setigero-punctate, substriate, without striole on apex or submarginal stria on sides; margin not interrupted posteriorly by an internal plica.

Anterior tibice elongate; external side hardly oblique above apex; a short acute spur a little above apex externally.

Apparently this genus represents a distinct group among the Subulipalpi The absence of the slightest interruption of the margin of the elytra towards the apex or of any sign of a plica on the inner side of the elytra near the margin seems an important 
character. Dr. G. H. Horn, in his definition of the Bembidiini, makes "the margin interrupted posteriorly and with a distinct internal plica"* an important feature of the tribe.

\section{Pyrrotachys constrictipes, n.sp.}

Elongate, parallel, depressed. Mandibles long, decussating; labrum deeply emarginate; antennæ with all the joints pubescent; prothorax transverse, narrowed to base; elytra pubescent, finely striate. Ferruginous; head reddish, eyes and adjacent parts black; elytra more obscurely coloured than prothorax, fuscous along suture and towards apex; legs testaceous; under parts of head and prothorax reddish, of body fuscous; antennæ testaceous at base, infuseate towards apex.

Head strongly bi-impressed; vertex convex, finely punctulate; impressions curved, diverging anteriorly and posteriorly, extending to sides of head behind eyes; front depressed between impressions; spaces between impressions and eyes convex, projecting sharply at base beyond sides of head; eyes prominent. Labrum large, deeply emarginate, a transverse linear impression a little before base. Prothorax depressed, transverse, widest at anterior marginal puncture, lightly narrowed to base, evidently wider at apex than base; sides very lightly rounded, shortly sinuate before posterior angles; anterior margin truncate; anterior angles obtuse; base truncate, a little oblique on each side behind posterior angles; these prominent, obtusely dentiform; a short depressed space along base, the impression defining this space curved forward in middle; median line well marked, not reaching either margin. Elytra narrow, a little wider than prothorax $(1.7 \times 1 \mathrm{~mm}$.), depressed, parallel on sides, truncate at base, widely and evenly rounded (without sinuosities) at apex; whole upper surface covered with a short pubescence; striæ very fine, not perceptible after the fourth; marginal channel hardly impressed along sides, marked and punctate near shoulders; interstices flat;

* Vide Trans. Am. Ent. Soc. 1s8!, ix. p. 133. 
three discoidal punctures on each elytron placed as in T'achys leai, Sl.

Length $2 \cdot 25-3$, breadth $0 \cdot 75-1 \mathrm{~mm}$.

Hab. : N.S. Wales-Tamworth (Lea).

The description is founded on a specimen of the largest size. Mr. Lea regards the smaller specimens as representing a different species from the larger ones, but I have been unable to follow him in this; though, as the collector of a large number of specimens and a careful observer, his opinion in this matter should outweigh mine.

\section{Appendix.}

Specimens of a new species of Tachys were received from Mr. A. M. Lea after the completion of my notes on the genus, and too late to enable it to be put into its proper place according to the table of species given on p. 356; however its affinities will be found indicated in the note following the description below.

\section{TACHys OLLIFfi, n.sp.}

Robust, oval, convex; prothorax rather short, subcordate; five discoidal punctate striæ, a finely punctate submarginal stria and a well marked apical striole on each elytron. Black; legs, upper side of mandibles and basal joint of antennæ testaceous; antennæ and palpi fuscous.

Head lævigate, convex; front lightly bi-impressed. Antennæ short, stout. Prothorax lævigate, transverse, subcordate; sides rounded, narrowed to base, shortly subsinuate before basal angles; anterior angles rounded, not marked; posterior angles subrectangular, slightly obtuse at summit; lateral border reflexed; lateral basal impressions wide, deep, short, extending to margin at basal angles; a light impression across base between lateral foveæ; median line obsolete. Elytra a little wider than prothorax, convex, declivous on base; sides lightly rounded; first stria entire, punctate anteriorly; striæ 2-5 consisting of rows of punctures on dise becoming successively shorter (the punctures fewer, larger and more distant from one another in fourth and fifth rows); 
submarginal stria not impressed on sides, but consisting of a row of fine punctures near margin; marginal channel hardly impressed, finely punctate; submarginal interstice depressed on sides; third interstice with two fine setigerous punctures.

Length $2 \cdot 2$, breadth $0.85 \mathrm{~mm}$.

Hab. : N. S. Wales-Forest Reefs.

Allied to T. finclersi, Blkb., from which it differs by its more convex shape, its colour; its prothorax with the sides less strongly sinuate posteriorly, the base narrower, the basal foveæ deeper, the basal angles less prominently acute, \&c. The prothorax appears to the eye of about equal width at base and apex.

Named in memory of Mr. A. S. Olliff, late Government Entomologist for New South Wales.

Note-With reference to my paper "On the Australian Clivinides (Fam. Carabidce)" in the preceding Part of the Proceedings, attention is called to the following :-

\section{CORRIGENDA.}

Page 150, line 14-for C. adelaidæ read C. tumidipes.

Page 171, line 20-for clypeus read clypeal.

Page 180-omit line 2.

Page 181, line 5-omit South Australia et seq.

Page 182, ine 27-for C. adelaidæ read C. tumidipes.

Page 195, line 18-for C. adelaidx, Blkb., read C. tumidipes, Sl.

Page 253, line 7-for C. adelaidæ read C. tumidipes.

Page 253, line 27-for on read in.

Page 254, line 29-for $C$. adelaidx read $C$. tumidipes.

Page 255, line 31-for C. tenuipes read C. gracilipes. 


\section{$2 \mathrm{BHL}$ Biodiversity Heritage Library}

Sloane, T G. 1896. "On the Australian Bembidiides referable to the genus Tachys, with the description of a new allied genus Pyrrotachys." Proceedings of the Linnean Society of New South Wales 21, 355-377. https://doi.org/10.5962/bhl.part.8477.

View This Item Online: https://www.biodiversitylibrary.org/item/30483

DOI: https://doi.org/10.5962/bhl.part.8477

Permalink: https://www.biodiversitylibrary.org/partpdf/8477

\section{Holding Institution}

MBLWHOI Library

\section{Sponsored by}

MBLWHOI Library

\section{Copyright \& Reuse}

Copyright Status: NOT_IN_COPYRIGHT

This document was created from content at the Biodiversity Heritage Library, the world's largest open access digital library for biodiversity literature and archives. Visit BHL at https://www.biodiversitylibrary.org. 